\title{
Corporate Social Responsibility and Employee Performance of Selected Nigerian Firms: A Structural Model Framework
}

\author{
Olanipekun, Wahid Damilola \\ PhD Candidate, Department of Business and Entrepreneurship, \\ School of Business and Governance, \\ College of Humanities, Management and Social Sciences, \\ Kwara State University, Malete, Nigeria \\ Corresponding author: olanipekundamilola@yahoo.com \\ Abdulraheem, Issa (PhD) \\ Department of Business and Entrepreneurship, \\ School of Business and Governance, \\ College of Humanities, Management and Social Sciences, \\ Kwara State University, Malete, Nigeria \\ Brimah, Aminu Nassir (PhD) \\ Department of Business and Entrepreneurship, \\ School of Business and Governance, \\ College of Humanities, Management and Social Sciences, \\ Kwara State University, Malete, Nigeria
}

\begin{abstract}
The study examined the relationship between CSR and employee performance using a structural equation model framework. Survey research design was used in the study. Data for this research was obtained from Primary sources through the aid of a structured questionnaire. Krejche and Morgan formular were used to estimate the sample size. 384 copies of questionnaires were administered to employees of the selected companies out of which only 305 copies were found to be useful for data analysis. The data were analyzed using descriptive statistics and inferential statistics of partial least square structural equation model (PLSSEM). The hypothesis was tested at 0.05 alpha levels. Findings revealed that social responsibility and sustainability is the variable that best predicts the employee performance with the following values $(\beta=.378$, $\mathrm{t}=4.388, \mathrm{p}=.000)$. The next vital predictor in order of importance is the economic responsibility and sustainability $(\beta=.227, t=3.263, p=.001)$ and finally, environmental responsibility and sustainability $(\beta=$ $.172, \mathrm{t}=2.931, \mathrm{p}=.003)$ is significantly related to employee performance. Based on the findings, the study concluded that CSR philosophy facilitates the unlocking of the human capital which makes significant contribution to the success of an organisation. The study recommends that organisations should pursue CSR initiative by integrating CSR strategies with their human resource policies. They must acknowledge that having a particular concern for the welfare of their employees goes a long way to boost the employee's commitment and by extension, their performance and ultimately the growth of the organisation.

Keywords: Corporate Social Responsibility, Sustainability, Development, Employees, Performance

Journal Reference Format:

Olanipekun, W.D., Abdulraheem, I. \& Brimah, A.N. (2019): Corporate Social Responsibility and Employee Performance of Selected Nigerian Firms: A Structural Model Framework. Humanities, Management, Arts, Education \& the Social Sciences Journal. Vol. 7 . No.1, Pp 21-30. Article DOI: dx.doi.org/10.22624/AIMS/HUMANITIES/V7N1P3.

Available online at www.humanitiesjournal.org
\end{abstract}




\section{INTRODUCTION}

The rise in the global discourse on CSR has changed the narrative with respect to how corporate organizations do business in the global market. There are various strategies that organizations now employ for dealing with the interaction of societal needs, the natural environment and corresponding business imperatives. Several organizations now adopt a wide range of voluntary initiatives associated with improvement in working conditions, environmental performances and company relations with workers, consumers, local community, and other stakeholders, others continue to wrestle with the challenges of integrating economic, social and environmental expectations of their stakeholders into the overall business operations. Tsoutsoura (2004) opined that the rise in the global importance of CSR has birthed several guidelines and standards like the Global Reporting Initiative (GRI), The Global Sullivan Principles of 1991, Global Compact of 2002, AA1000/AA1000AS of 1999 and 2008, the Social Venture Network Standards and the ISO 26000. These codes and standards were introduced in response to the pressure by civil rights and environmental activist groups.

In Nigeria, Lawal and Brimah (2012) stated that there are many reasons that can be adduced to justify the need for upsurge in social responsibility implementation especially by organisations. One, the community and its business sector have a symbiotic relationship. They are interdependent and should reinforce one another. Since organizations form part of the society, the society should also be concerned about the wellbeing of the organisations' business in the same way as they should be concerned about societal welfare. Thus, the notion of corporate social responsibility stems from the long conviction that businesses have a responsibility to 'give something back' to the communities where they operate. In the time past, initiatives have been designed to 'give something back' to host communities, especially by the oil and gas multinational companies, where it is believed that the history of formalized CSR in Nigeria began (Abdullahi, Lawal, Ijaiya \& Ibrahim, 2012). Organizations are increasingly beginning to understand the importance of CSR and subsequently creating value in the society through its practices since it increases productivity, contribute to competitiveness and creates positive brand image in the eyes of the investors, creditors, competitors, employees, government and the society at large.

Inclusion of CSR in mission statements and dedication of a section of annual report to CSR is common among successful and competitive organizations because it holds special appeal to stakeholders. It is an accepted fact that most companies the world over are embracing practices that engenders sustainable reporting. Global Reporting Initiative (2011) opined that "thousands of organizations worldwide now produce sustainability reports. Similarly, KPMG International Survey of 2011 which covers 34 countries (Nigeria inclusive) shows that 95 percent of the 250 largest global companies now report on their corporate responsibility activities. This is in response to the demand for organisations to be more transparent in how they treat their economic, social and environmental activities as they affect their stakeholder. One of such stakeholders is the employees

Employees are one of the most pivotal stakeholders of an organization because they can be influenced by and also influence the organizations activities thus playing an essential role in organizational effectiveness. Employees are expected to have opinions of their organization's CSR activities which can affect their level of participation and involvement. It is through employee actions and decision-making that many CSR strategies come to life. Employees are in a unique position to nurture and foster CSR performance within their organizations" (Strandberg, 2009). Employees by virtue of the strategic position they occupy are well positioned to contribute significantly with respect to the effective implementation of CSR practices and 
policies. As a key stakeholder of the firm, Zappala (2004) opined that employees should be seen as an asset to be developed and valued. The involvement of employees underscores the strategic importance of the human resource management (HRM) in the CSR initiative of an organization. There is, in fact, growing evidence that human resources provide firms with competitive edge (Pfeffer, 2000).

Despite the germane roles of employees, the perception of employees towards the CSR practices and policies is usually given the least attention by the management team (Rupp, Ganapathi, Aguilera, \& Williams, 2006). This seems ironic given the pivotal role of employees in an organization. They are the ones who directly witness, perceive and evaluate the CSR activities carried out by their organizations. Employee as an important key of an organization needs a good motivation, so that employee can work as well as possible. Hence, it becomes important to study various factors associated with corporate social responsibility from the employee's perspective. Mirfazli (2008) posits that failure to engage in CSR practices will cause more harm to a business than good because social and ethical responsibilities do attract and retain the best workers in any organization. From the forgoing, the main thrust of this study is to examine the impact of CSR on employee performance of selected firms in Nigerian Banking and Manufacturing Industry

\section{LITERATURE REVIEW}

\subsection{Conceptual Definitions of CSR}

CSR has been conceptualized in various ways by different writers, thus, there are a myriad of definition of CSR. The majority of these definitions have attempted to integrate the three dimensions to the concept; economic, environmental and social dimensions. Caroll (1979) asserts that CSR encompasses philanthropy and community contributions but also reflects the way in which the firm interacts with the physical, environment and its ethical stance towards consumers and other stakeholder. World Business Council for Sustainable Development (WBSCD, 2000) defines CSR as "the continuing commitment of business to behave ethically and contribute to economic development while improving the quality of life of the workforce and their families as well as that of the local community and society at large".

Dahan and Senol (2006) aver that CSR is defined through the ethical relationship and transparency of the organisation with all its stakeholders that has a relationship as well as with the establishment of corporate goals that are compatible with the sustainable development of society, preserving environmental and cultural resources for future generations, respecting diversity and promoting the reduction of social problems. Hopkins (2004) opines that CSR is a business concept that facilitates organizations ability to behave in a socially and environmentally responsible ways so that its business contributes to society in meaningful and lasting ways.

Asada (2010) further observes that CSR practices of corporations places premium not only on their business operations such as profits, return on investment, dividend payment, but also with respect to social, environments, health, education and other consequences. Nwosu (1996) says that CSR promotes welfarism of people and society by restraining individuals and corporate entities (government) from engaging in policies that will portray them as callous.

\subsection{Theoretical Framework - Stakeholder Theory}

Stakeholder theory is one fundamental approach that several scholars have employed in defining and developing CSR (Post, 2003). It is upon this theory that this present study hinges. The theory suggests that survival and success of an organizations will be determined to a large extent on its ability to satisfy its 
economic (e.g., profit maximization) and non-economic (e.g., corporate social performance) objectives by meeting the needs of the company's various stakeholders (Pirsch, Gupta, \& Grau, 2007). Freeman, Wicks, and Parmar (2004) opined that stakeholder theory begins with the assumption that values are necessarily and explicitly a part of doing business. It asks managers to articulate the shared sense of the value they create, and what brings its core stakeholders together.

It also pushes managers to be clear about how they want to do business, specifically what kinds of relationships they want and need to create with their stakeholders to deliver on their purpose. Thus, Popa, Blidisel and Bogdan (2009) aver that the stronger the companies' relationships are with its diverse stakeholders, the easier it will be to achieve vision and mission. Stakeholder theory contributes to the corporate sustainability concept by bringing supplementary business arguments as to why companies should work toward sustainable development. Also, Perrini and Tencati (2006) states that the success and continuous survival of a firm depends on the sustainability of its stakeholder relationships; a company must consider and engage not only shareholders, employees and clients, but also its diverse stakeholders.

\subsection{Empirical Review on CSR and Employee Performance}

Joseph, Jerome, \& Mahmood, (2015) conducted a study on that examined the Link between Employees Job Performance and CSR in the Banking Industry in Nigeria. The study examined the link between employees' job performance and corporate social responsibility in the commercial banks in Nigeria. Quantitative and qualitative methods were used to obtain data through a self-administered questionnaire survey, a number of semi-structured in-depth expert interviews and content analysis. The case study organization was selected because the majority of studies conducted in Nigeria on similar or related topics were conducted on business or public organizations. The outcome of the quantitative and qualitative analysis reveals that there is a link between employees job performance and corporate social responsibility.

Paulík, Felix \& Aleksandar (2015) conducted a study on CSR as a driver of satisfaction and loyalty in commercial banks in the Czech Republic. The aim of the paper was to whether CSR strategy of bank affects satisfaction and loyalty of bank customers and employees. A quantitative method of questionnaire survey and descriptive statistics was used to analyze data to support the research results. Findings revealed that $87 \%$ of Czech bank customers are satisfied with their banks. There was a positive relationship between customer satisfaction and customer loyalty.

Khaled, Mohammed, Ahmed (2017) examined Employees' Satisfaction and CSR practices in Egyptian firms. The authors examined the impact of five dimensions of Social Accountability Standards (SA8000) practices on employee satisfaction: Health and safety, unions and bargaining right, discrimination, work life balance and sufficient wage. A proposed model was tested on a sample of 199 employees, which represents 49\% response rate, within an Egyptian firm that is operating within the textile industry. Results showed that all internal CSR dimensions are significantly and positively related to satisfaction. In addition, the findings of the present study provided evidence to suggest a model can be developed to enhance satisfaction based on CSR practices

Ahmad, Islam \& Saleem, (2017) conducted a study on Employee Engagement, Organizational Commitment and Job Satisfaction as Consequent of Perceived CSR. The study aimed at examining organizational commitment and employee engagement as consequent of perceived CSR with the mediating role of job satisfaction. A questionnaire based survey was used to collect data from 736 faculty members of higher education institutions. Hypotheses were tested using structural equation modeling. Findings revealed that, perceived CSR positively influence employees level of engagement and commitment towards their organization, whereas, this mechanism is partially supported considering job satisfaction as a mediating 
variable. This study is novel and has implications for the higher education institutions

Franco \& Suguna (2016) conducted a study on Corporate Social Responsibility Influences, Employee Commitment and Organizational Performance. This study analyzed the multifaceted influence CSR on employee organizational commitment and organizational performance. Variables such as turnover, absenteeism and low motivation towards work and organization were concerns that were identified. The findings of the study revealed that CSR practices had significant impact on employee commitment and organizational performance. Aditya \& Saily (2015) conducted a study on effects of CSR on employee satisfaction and commitment. The purpose of the research was to find out the impact of CSR on motivation and commitment of an Employee in the organization. 60 respondents were taken as the sample size. The perceptions of employees working in IT and Hospitality sector of Allahabad and Pune in India who have implemented CSR activities for at least 1 year were surveyed via a structured questionnaire. Findings revealed that there exists a strong correlation between the CSR practices an employee participates and the duration of his tenure in the organization.

Santoso (2014) conducted a study on the effect of Internal CSR towards Employee Engagement and Affective Commitment in XYZ Hotel Surabaya. This study evaluated the impact of internal CSR through the organizations HR policies and employee engagement and affective commitment. Questionnaires were administered to 90 employees in XYZ Hotel Surabaya and the hypothesis were tested using regression analysis. Findings from the result revealed that health and safety practices were the strongest predictor that influenced employee engagement and commitment. Yousafa, Alib, Ali, Muhammad (2016) conducted a study on effect of Internal CSR on Employee Engagement a Study of Moderated Mediation Model. The study employed a cross sectional quantitative study using a sample size of 163 employees of five major commercial banks operating in Pakistan. A structured questionnaire was used to collect data. Findings from the results revealed that internal CSR has direct impact and indirect impact through employee perception on employee engagement.

\section{METHODOLOGY}

The study population constitutes all the firms in both Nigerian banking and manufacturing industry. For the banking industry, the study population was banks categorized as Tier 1 (Zenith Bank Plc, UBA Plc, GTBank Plc, FBN Plc, and Access Bank Plc) and adjudged to be controlling 60 percent of banking sectors assets in Nigeria (Akanbi 2014). The firms in the manufacturing industry were selected from the Food and Beverage Group. The firms are Cadbury Nigeria Plc, Flour Mills Nigeria Plc, Nestle Nigeria Plc, UACN Nigeria Plc, and Unilever Nigeria Plc. All ten firms were selected using purposive sampling having constantly and continuously disclosed their CSR activities explicitly in the last ten years. This survey research was mainly based on primary data collected from employees of selected firms. Primary data were used in this study. A sample was drawn from the population, hence; a sample size of three hundred and sixty (384) respondents constitutes the sample size for questionnaires that were administered to the staff respondents which was arrived at using Krejcie and Morgan's (1970) sample size determination criteria

Out of the 384 copies of the questionnaire given out, 305 copies of questionnaire were filled appropriately and useful for analysis. Data collected from the questionnaire were analyzed with the aid of a Structural Equation Model (SEM) because it is a tool which allows treatment of data analysis with multivariate relationships involving one or more independent variables against one or more dependent variables (Smith, 2004; Daud, Mohamed and Alhamali, 2009). The primary reason for adopting SEM is the ability to frame and answer increasingly complex questions about data (Kelloway, 1998). It is more advanced than factor 
analysis and multiple regression analysis, but combines essential rudiments of both techniques for confirming intercorrelated dependent relationships simultaneously within a model (Hair, Hult, Ringle, \& Sarstedt, 2014; Sweeney, 2009). SmartPLS 3.0 statistical package was used for the analysis because it is a powerful multivariate analysis technique that includes specific versions of a number of other analysis methods as special cases. The hypotheses were tested at $5 \%$ level of significance.

\subsection{Test of Hypotheses}

Ho:- CSR does not have any significant impact on employee performance of selected firms in Nigerian Banking and Manufacturing Industry

H1a: Economic responsibility and sustainability does not have any impact on employee performance H1b: Social responsibility and sustainability does not have any impact on employee performance H1c: Environmental responsibility and sustainability does not have any impact on employee performance

\section{RESULTS AND DISCUSSION OF FINDINGS}

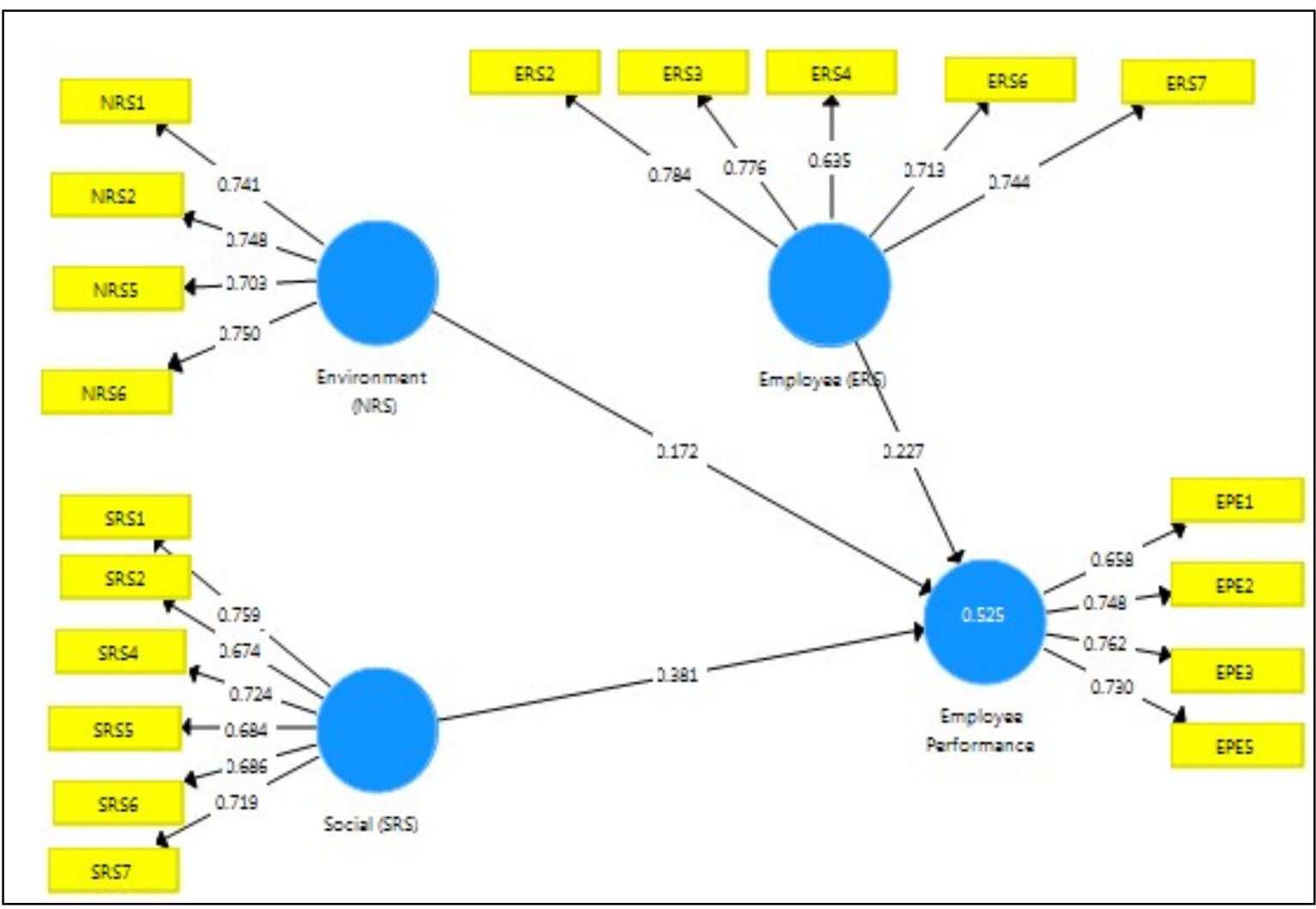

Figure 1: Result for Reflective Measurement Model Algorithm for Employee Performance 


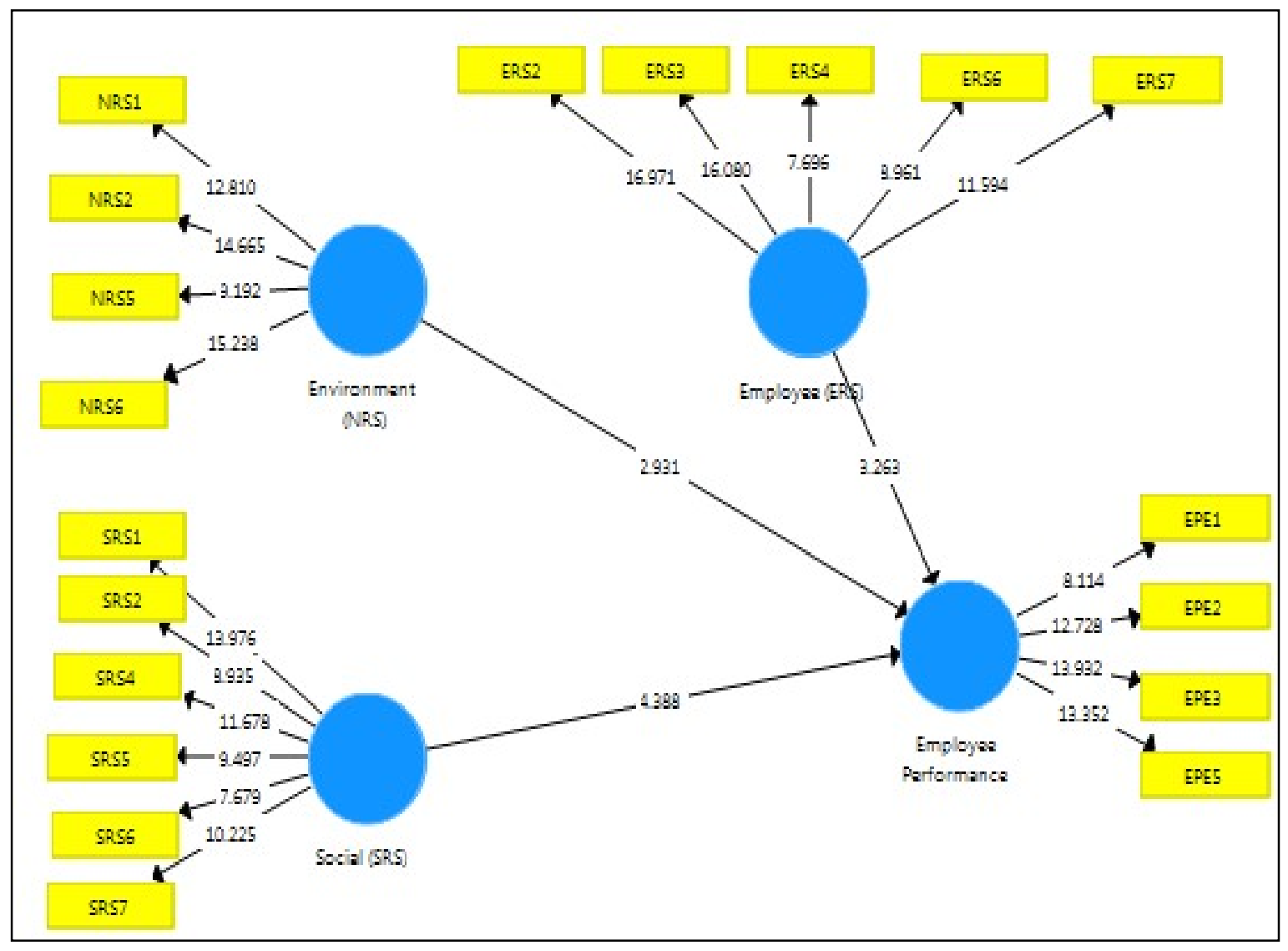

Figure 2: Results of Bootstrapping on Structural Model (Employee Performance)

Table 1: Results of Hypotheses Testing One (1)

\begin{tabular}{|l|l|c|c|c|c|}
\hline Hyp. & Relationship & Beta & S.Error & T - value & P -value \\
\hline $\mathbf{H}_{\mathrm{la}}$ & Economic (ERS) -> Employee Performance & 0.227 & 0.070 & 3.263 & 0.001 \\
\hline $\mathbf{H}_{\mathrm{lb}}$ & Environment (NRS) ->Employee Performance & 0.172 & 0.059 & 2.931 & 0.003 \\
\hline $\mathbf{H}_{\mathrm{lc}}$ & Social (SRS) ->Employee Performance & 0.378 & 0.087 & 4.388 & 0.000 \\
\hline
\end{tabular}

Note: Three of the hypotheses are supported based on their T-values (T-value 21.96 ).

Hypothesis 1a predicted that CSR (economic) related to employees' performance. Result (Table 1, Figure 1) revealed a significant positive relationship between CSR (economic) and employees' performance $(\beta=$ $0.227, \mathrm{t}=3.263, \mathrm{p}=0.001)$. Therefore, Hypothesis 1a is supported.

Hypothesis 1b predicted that CSR (environment) is related to employees' performance. Result (Table 1, Figure 1) showed a significant positive relationship between CSR (environment) and employees' performance $(\beta=0.172, t=2.931, \mathrm{p}=0.003)$. Hence the hypothesis $1 \mathrm{~b}$ is aligned with.

In addition, in examining the influence of CSR (social) on employees' performance, result indicated that 
CSR (social) had a significant positive relationship with employees' performance with $(\beta=0.378, t=4.388$, $\mathrm{p}=0.000)$. Hypothesis $1 \mathrm{c}$ is supported.

The finding above shows that CSR significantly relate to the employee performance. The discussion on the relationship between individual employee performance (economic, social and environmental) was offered individually. Among the three hypothesis, social responsibility and sustainability is the variable that best predict the employee performance with the following values $(\beta=.378, \mathrm{t}=4.388, \mathrm{p}=.000)$. The next vital predictor in order of importance is the economic responsibility and sustainability $(\beta=.227, \mathrm{t}=3.263, \mathrm{p}=$ $.001)$ and finally, environmental responsibility and sustainability $(\beta=.172, t=2.931, p=.003)$ is significantly related to employee performance. All the three independent variables impacted on the directional hypothesis. Therefore, hypothesis $\mathrm{H}_{\mathrm{ta}} \mathrm{H}_{\mathrm{b}}$ and $\mathrm{H}_{\mathrm{c}}$ are supported. The findings of this study is consistence with previous findings of Korschun, Bhattacharya, and Swain, (2014) and Bai and Chang (2015) whose studies indicted a positive relationship between CSR and employee performance.

\section{CONCLUSION AND RECOMMENDATIONS}

The dynamism in 21st century has changed the landscape of business activities. One of the changes is organizations thinking beyond meeting only the economic bottom line of profitability. CSR, stemming from internal values or social and environmental pressures, is becoming the norm. The global emphasis is how organisations' can strategically engage in CSR, satisfy its diverse and numerous stakeholders and reap the long term benefits of such engagements. Employees by virtue of their human nature have not only economical, but also social and emotional expectations from their companies. Hence, adoption and engagement in CSR practices can be used to meet and fulfill their expectations from organizations. When employees expectations are met and surpassed through CSR practices, their affective and normative commitments would also increase thereby, undoubtedly reinforcing the organizational commitment of employees (Peterson, 2004). Simultaneously, such companies also will have improved goodwill, brand value and better reputation from the point of view of the employees and the society, and hence more job satisfaction will be observed

Given the already intense pressure brought by stakeholders globally on utilization of resources in line with the principles of sustainable development that underpins the concept of CSR, There is need for the enshrinement of the CSR philosophy in all organizations in order to achieve a sustainable development that the $21^{\text {tt }}$ century demands. Companies should maintain, sustain and improve on the current tempo of CSR initiatives

\section{REFERENCES}

1. Abdullahi, I.B., Lawal, W.A., Ijaiya, M.A., \& Ibrahim, R.O. (2012). Corporate social responsibility: Experience from the Nigerian environment. Entrepreneurial Journal of Management Sciences. 1(1), 189-197.

2. Ahmad, R., Islam, T., \& Saleem, S. S. (2017). Employee engagement, organisational commitment and job satisfaction as consequent of perceived CSR: a mediation model. Journal of the Research Society of Pakistan, 54(1).

3. Akanbi, F. (2014, May 5). Nigeria's top banks: How they rank. Thisday, P.B.

4. Asada, D. (2010). Corporate social responsibility of companies and sustainable development in Nigeria: Recent trends and lessons from other African 
Countries.http://dspace.unijos.edu.ng/bitstream/10485/1449/1/

Corporate\%20Social\%20Responsibility\%20of\%20Companies .pdf. Accessed 29/5/2013.

5. Bai, X., \& Chang, J. (2015). Corporate social responsibility and firm performance: The mediating role of marketing competence and the moderating role of market environment. Asia Pacific Journal of Management, 32(2), 505-530.

6. Carroll, A. B. (1979). A three-dimensional conceptual model of corporate performance. The Academy of Management Review, 4(4), 497-505.

7. Global Reporting Initiative (2011). Sustainability reporting guidelines version 3.1. Retrieved from https://www.globalreporting.org/resourcelibrary/G3.1Guidelines-Incl-Technical- Protocol.pdf

8. Hair, J. F., Hult, G. T. M., Ringle, C. M., \&Sarstedt, M. (2014). A primer on partial least squares structural equation modeling (PLS-SEM). Thousand Oaks: SagePublications

9. Hopkins, M. (2004). “Corporate Social Responsibility: An Issues Paper”. Working Paper No. 27, World Commission for Social Dimension of Globalization, ILO, Geneva. Available from http://www.ilo.org/wcmsp5/groups/public/---dgreports/--integration/ documents/publication/wcms_079130.pdf. Accessed: 1st October 2016.

10. Khalid, O., Mohammed, M., \& Ahmed, P. (2017). The Impact of Corporate SocialResponsibility on Organizational Commitment: Exploring Multiple Mediation Mechanisms. Journal of Business Ethics. 1, 4(5), 12-30

11. Korschun, D., Bhattacharya, C. B., \& Swain, S. D. (2014).Corporate social responsibility, customer orientation, and the job performance of frontline employees. Journal of Marketing, 78(3), 20-37.

12. Krejcie, R. V., \& Morgan, D. W. (1970). Determining sample size for research activities Educational and psychological measurement 1970, 30, 607-6 10.

13. Joseph, J.H., Jerome, K.M., \& Mahmood, J.D., (2015) 'The Link between employees jobperformance and corporate social responsibility in the Nigeria banking industry in Nigeria' Journal of Vocational Behavior, Vol. 63, pp. 510 - 531.

14. Kelloway, E. K. (1998) Using LISREL for structure equation modelling: A researcher's guide, Newbury Park, CA: Sage

15. Lawal, A.T and Brimah, A.N (2012). Financial Determinants of Corporate Social Responsibility Uptake in Nigeria Deposit Banks: The Zenith Bank Experience, LapaiJournal of Management and Social Sciences, 3(1), 68-76.

16. Mirfazli, E. (2008), "Corporate social responsibility (CSR) information disclosure by annual reports of public companies listed at Indonesia Stock Exchange (IDX)", International Journal of Islamic and Middle Eastern Finance and Management, 1 (4): 275 - 284

17. Paulík, J., Kombo, F., \& Ključnikov, A. (2015). CSR as a driver of satisfaction and loyalty in commercial banks in the Czech Republic. Journal of International Studies.

18. Pfeffer J. and Salancik G.R. (2003): The External Control of Organizations: A Resource Dependence Perspective, California: Stanford University Press

19. Pirsch, J., Gupta, S., and Grau, S. L. (2007). A framework for understanding corporate social responsibility programs as a continuum: An exploratory study. Journal of Business Ethics, 70:125140 .

20. Post, F. R. (2003). "The Social Responsibility of Management: A Critique of the Shareholder Paradigm and defense of Stakeholder Primacy, Mid - American Journal of Business, 18(2):57-63.

21. Rupp, D., Ganapathi, J., Aguilera, R., \& Williams, C. (2006). Employee reactions to corporate social responsibility: an organizational justice framework. Journal of organizational behaviour, 27, $537-543$

22. Santoso, I. L. (2014). The impact of internal CSR towards employee engagement and affective 


\section{Humanities, Management, Arts,}

Education \& the Social Sciences

commitment in XYZ hotel Surabaya. iBuss Management, 2(2).

23. Sweeney, L. (2009) A Study of Current Practice of Corporate Social Responsibility (CSR) and an Examination of the Relationship between CSR and Financial Performance Using Structural Equation Modeling (SEM).Doctoral Thesis. Dublin Institute of Technology, Dublin

24. Smith, I. (2004).Human resource development - measuring return on investment. Library Management, 25, 6, 318-20.

25. Tsoutsoura, M. (2004). Corporate social responsibility and financial performance. In possession of Center for Responsible Business, Working Paper Series, paper 7, University of California. Berkeley

26. World Business Council for Sustainable Development (2000), Corporate Social Responsibility:Making Good Business Sense, WBCSD, available at: www.wbcsd.org/ (Accessed: 10-07-2016). 